
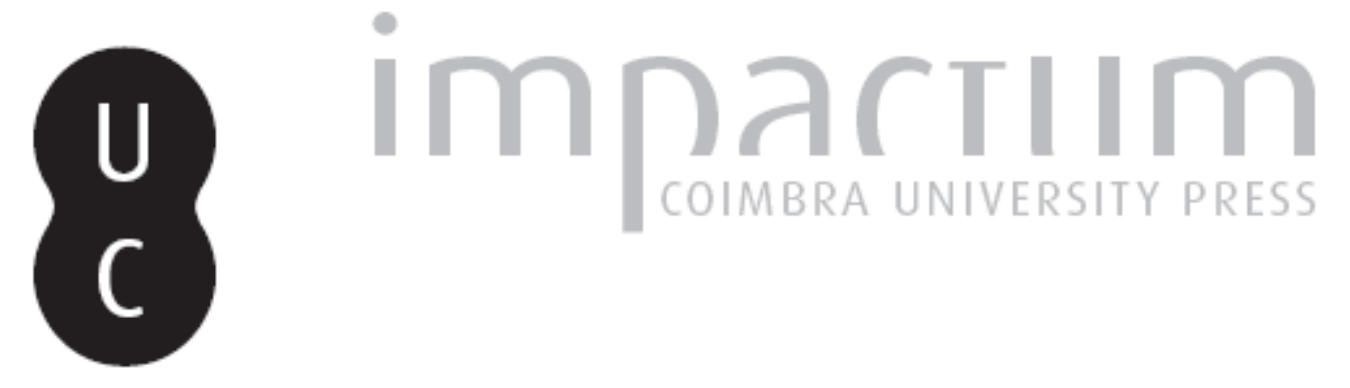

\title{
[Recensão a] The Renaissance. Essays in Interpretation
}

Autor(es): $\quad$ Rodrigues, Manuel Augusto

Publicado por: Imprensa da Universidade de Coimbra

URL persistente:

URI:http://hdl.handle.net/10316.2/45111

DOI:

DOI:https://doi.org/10.14195/2183-8925_7-2_23

Accessed : $\quad$ 26-Apr-2023 11:33:53

A navegação consulta e descarregamento dos títulos inseridos nas Bibliotecas Digitais UC Digitalis, UC Pombalina e UC Impactum, pressupõem a aceitação plena e sem reservas dos Termos e Condições de Uso destas Bibliotecas Digitais, disponíveis em https://digitalis.uc.pt/pt-pt/termos.

Conforme exposto nos referidos Termos e Condições de Uso, o descarregamento de títulos de acesso restrito requer uma licença válida de autorização devendo o utilizador aceder ao(s) documento(s) a partir de um endereço de IP da instituição detentora da supramencionada licença.

Ao utilizador é apenas permitido o descarregamento para uso pessoal, pelo que o emprego do(s) título(s) descarregado(s) para outro fim, designadamente comercial, carece de autorização do respetivo autor ou editor da obra.

Na medida em que todas as obras da UC Digitalis se encontram protegidas pelo Código do Direito de Autor e Direitos Conexos e demais legislação aplicável, toda a cópia, parcial ou total, deste documento, nos casos em que é legalmente admitida, deverá conter ou fazer-se acompanhar por este aviso.

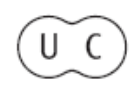




\section{REVISTA DE HISTORIA DAS IDEIAS 7}

\section{REVOLTAS E REVOLUCOẼS}

\section{**}

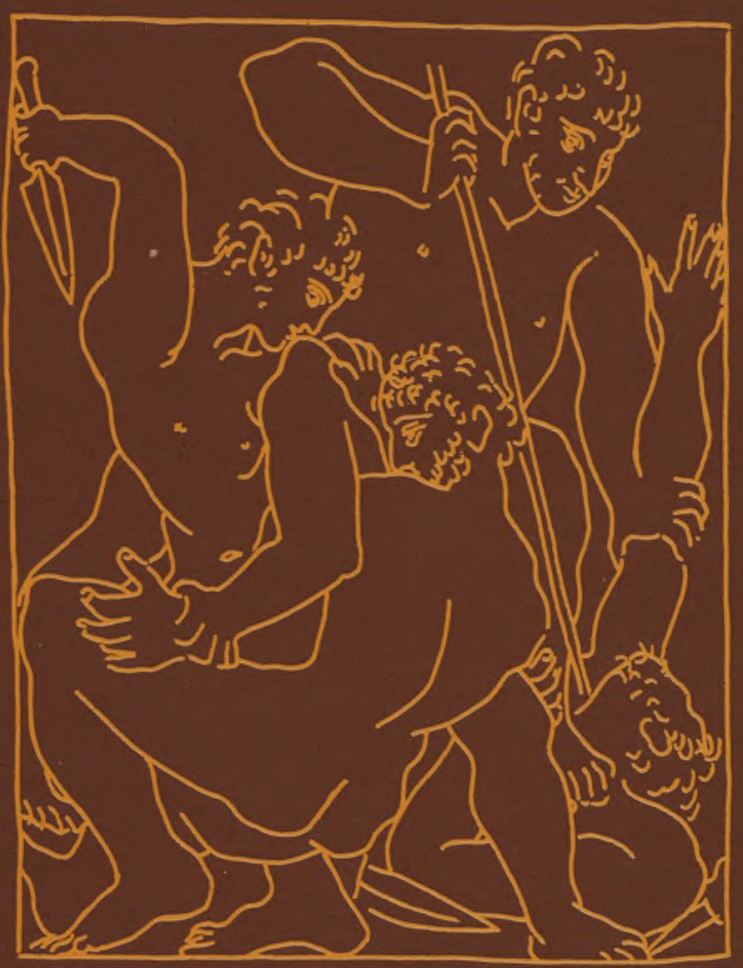

INSTITUTO DE HISTÓRIA E TEORIA DAS IDEIAS FACULDADE DE LETRAS 


\section{Revista de Historia das Ideias}

ticos e as reformas se faziam sentir com enorme peso. O trabalho de Hengst é uma tentativa altamente louvável de mostrar que o papel das Universidades jesuíticas e dos padres da Companhia nas Universidades se revelou deveras importante. $\mathrm{O}$ autor limita-se ao período do absolutismo confessional e às regiões da Alemanha setentrional e do Reno. No desenvolvimento que faz ao longo do livro o autor esclarece vários pontos, utilizando prevalentemente fontes do Arquivo da Companhia de Roma. Os diversos capítulos da obra abrangem temas candentes como a estrutura e a organização do plano de estudos da ordem, para, a partir daí, passar a referir a influência exercida sobre as disciplinas e as Faculdades de Filosofia e de Teologia, quer da Igreja quer estatais. A segunda parte trata das Escolas Superiores confiadas à Companhia. 12 mapas no fim do livro e 34 documentos ilustram admiravelmente esta obra.

\section{Manuel Augusto Rodrigues}

The Renaissance. Essays in Interpretation, London-New York, Methuen, 1982. 336 p.

Este conjunto de nove estudos dedicados à Renascença e consagrados à figura de Eugênio Garin, um dos nomes mais célebres da história do pensamento do séc. XVI, foi publicado primeiro em italiano (Roma-Bari, 1979). Também os autores dos trabalhos incluídos na obra se têm evidenciado como mestres altamente qualificados da época quinhentista que se impuseram pelo seu saber e larga experiência. São eles: Denys Hay, Walter Ullmann, Charles Trinkaus, Paul Oskar Kristeller, Nicolaï Rubinstein, Cecil Grayson, André Chastel, Marie Boas Hall e Charles B. Schmitt. Os assuntos abordados com profundidade e clareza apreciáveis incidem sobre a historiografia da Renascença durante o último quartel que a iniciou, as origens medievais da Renascença, o tema da «humanistas» (que engloba a «dignidade» e a «miséria» do homem), o lugar da Renascença na história do pensamento filosófico, um panorama das teorias políticas aparecidas então, o terreno da história literária (embora reduzido à Itália) e o das artes (com uma análise da aspiração à beleza, princípio universal de uma actividade que enforma toda a natureza - «natura artifex» - , sendo os dois últimos estudos consagrados à actividade científica, quer no respeitante à filosofia quer no tocante ao ensino nas Universidades italianas. 